\title{
Monitoring Suhu Tubuh dengan Output Suara Berbasis ESP-32CAM
}

\author{
Abdul Haris Kuspranoto* ${ }^{1}$, Frada Oktaruli Sinaga ${ }^{2}$ \\ Politeknik Bina Trada, Indonesia
}

INFO ARTIKEL

Alamat Web Artikel:

https://journal.umy.ac.id/index.php/ $\mathrm{mt} /$ article/view/11980

DOI:

https://doi.org/10.18196/mt.v3i1.11 980

Data Artikel:

Diterima:

22 Juni 2021

Direview:

30 Agustus 2021

Direvisi :

23 September 2021

Disetujui :

30 September 2021

Korespondensi:

abdulhariskuspranoto

@ polbitrada.ac.id

\begin{abstract}
ABSTRAK
Pada masa pandemik sekarang ini, pemerintah Indonesia menerbitkan kebijakan tentang protokol kesehatan (prokes) untuk mencegah semakin meluasnya dampak pandemik. Salah satu prokes yang harus dilakukan adalah pengukuran/pemeriksaan suhu tubuh. Umumnya ditempat keramaian pengukuran suhu tubuh menggunakan thermometer gun dan membutuhkan operator untuk mengoperasikannya sehingga dinilai cukup rawan penularan dari orang yang terjangkit kepada operator atau sebaliknya. mengurangi penularan tersebut, perlu dikembangkan sebuah thermometer jenis gun berbasis infra red yang menggunakan sensor MLX90614. Dalam penelitian ini telah dirancang sebuah alat yang dapat digunakan untuk mengukur suhu manusia dengan nilai pembacaan yang akurat menggunakan sensor MLX90614 yang dipadukan dengan ESP32-CAM serta LCD TFT. Hasil rata-rata pengukuran pada jarak $3 \mathrm{~cm}$ mempunyai galat sebesar $0,58 \%$, hasil rerata pengukuran pada jarak $5 \mathrm{~cm}$ mempunyai galat sebesar $1,62 \%$, hasil rerata pengukuran pada jarak $7 \mathrm{~cm}$ mempunyai galat sebesar $1,67 \%$, hasil rerata pengukuran pada jarak $9 \mathrm{~cm}$ mempunyai galat sebesar 2,33\%, hasil rerata pengukuran pada jarak $11 \mathrm{~cm}$ mempunyai galat sebesar $2,44 \%$, hasil rerata pengukuran pada jarak $13 \mathrm{~cm}$ mempunyai galat sebesar 2,64\%, dan hasil rerata pengukuran pada jarak $15 \mathrm{~cm}$ mempunyai galat sebesar 2,83\%. Dari sistem ini diketahui bahwa semakin jauh jarak pengukuran maka akan semakin besar nilai galatnya. Dilihat dari hasil galat yang didapatkan maka sistem yang dibuat cukup akurat dalam melakukan pengukuran suhu manusia.
\end{abstract}

\section{Kata Kunci: ESP32-CAM, Sensor MLX90614, Suhu Tubuh}

\begin{abstract}
During the current pandemic, the Indonesian government issued a policy on health protocols to prevent the wider impact of the pandemic. One of the processes that must be done is by measuring/checking body temperature. Generally, in crowded places, body temperature measurement uses a thermometer gun and requires an operator, so it is considered quite prone to contract the virus from infected people to operators or vice versa. To reduce the transmission, it is necessary to develop an infrared-based gun-type thermometer with the MLX90614 sensor. In this research, a tool was designed to measure human temperature with accurate readings using the MLX90614 sensor combined with ESP32-CAM and TFT LCD. The average measurement result at a distance of $3 \mathrm{~cm}$ had an error of $0.58 \%$, at a distance of 5 $\mathrm{cm}$ with an error of $1.62 \%$, at a distance of $7 \mathrm{~cm}$ with an error of $1.67 \%$, at a distance of $9 \mathrm{~cm}$ with an error of $2.33 \%$, at a distance of $11 \mathrm{~cm}$ with an error of $2.44 \%$, at a distance of $13 \mathrm{~cm}$ with an error of $2.64 \%$, and at a distance of $15 \mathrm{~cm}$ with an error of $2.83 \%$. From this phenomenon, the farther the measurement distance, the greater the error value. Judging from the error results, the system is quite accurate in measuring human temperature.
\end{abstract}

Keywords: ESP32-CAM, MLX90614 Sensor, Body Temperature

\section{PENDAHULUAN}

Kesehatan merupakan sebuah harta berharga dalam keberlangsungan hidup manusia. Barubaru ini ditemukan sebuah virus yang cukup mematikan untuk keberlangsungan hidup manusia. Pada akhir tahun 2019 tepatnya pada bulan desember 2019 pandemi COVID-19 dimulai dari Wuhan China dan mulai menyebar serta menjangkit manusia hampir diseluruh belahan dunia [1]- 


\section{Kuspranoto, Sinaga}

Monitoring Suhu Tubuh dengan Output Suara Berbasis ESP-32CAM

[3]. Mengacu pada data World Health Organization (WHO) pada tanggal 28 Februari 2021, Covid19 telah menjangkit kurang lebih 113,467,303 kasus dengan tingkat kematian 2,520,550 [4].

Menularnya Covid-19 membuat dunia menjadi resah, termasuk di Indonesia. Untuk mengurangi penyebaran dan memutus rantai Covid-19 pemerintah menerbitkan protokol kesehatan yang wajib diterapkan di pusat perbelanjaan, kantor, hotel, hingga pusat keramaian lainnya, seperti menerapkan kebijakan pemeriksaan suhu tubuh setiap pengunjung [5], [6]. Umumnya disetiap gedung atau tempat keramaian seperti bandara, pusat pembelanjaan pemeriksaan suhu tubuh menggunakan pistol thermometer dan membutuhkan operator untuk mengoperasikannya sehingga dinilai cukup rawan menularkan dari orang yang terjangkit kepada operator atau sebaliknya.

Salah satu usaha yang dapat dilakukan untuk mencegah penyebaran Covid-19 adalah dengan menggunakan termometer yang tidak bersentuhan langsung dengan kulit manusia dan tanpa harus ada operator yang menjalankan alat tersebut. Penggunaan inframerah menjadi salah satu opsi dalam mengembangkan termometer jenis ini [7], [8]. Pada umumnya termometer yang sering digunakan untuk mengukur suhu tubuh manusia terbagi menjadi 2 yaitu analog dan digital. Terdapat pula termometer yang menggunakan air raksa. Apabila tabung pecah, air raksa merupakan zat yang beracun bagi manusia. Pada umumnya termometer analog maupun digital sama-sama membutuhkan waktu pengukuran suhu dalam hitungan menit dan menimbulkan kekhawatiran terjadinya infeksi nosokomial karena adanya kontak langsung dengan tubuh [9].

Termometer digital inframerah dirasa dapat membantu mengatasi salah satu masalah penularan Covid-19 karena tidak perlu dilakukan sentuhan dan angka yang muncul juga jelas serta memiliki ketelitian yang lebih baik[10]. Penggunaan termometer digital yang biasanya hanya menggunakan tampilan keluaran, namun kini telah banyak dilengkapi dengan kelebihan yang lain seperti keluaran suara. Kelebihan ini sangat efektif untuk pengguna termometer digital yang memiliki kekurangan dalam penglihatan[11]. Penelitian terkait rancang bangun termometer digital tanpa sentuhan sudah banyak dilakukan salah satunya pernah dilakukan pada tahun 2020 (Saputra, Karmel and Zainal, 2020), pada penelitian tersebut dirancang sebuah termometer digital inframerah menggunakan sensor MLX 90614 dan Sensor ultrasound HCSR04 yang bertujuan untuk mendeteksi suhu tubuh manusia dan menghitung jumlah pengunjung dengan tanpa adanya sentuhan

Pada penelitian ini dilakukan sebuah perancangan suatu alat pengukur suhu tubuh manusia sederhana secara otomatis dengan mendeteksi wajah manusia dan diharapkan pada penelitian ini, dapat memudahkan pengguna dalam penggunaan termometer digital karena dibantu dengan tampilan LCD dan keluaran suara sebagai nilai tambah pada rancangan alat ini.

\section{METODE PENELITIAN}

Penelitian rancang bangun sistem pemantau suhu berbasis ESP32-CAM ini melalui beberapa tahapan yang ditunjukkan pada Gambar 1 .

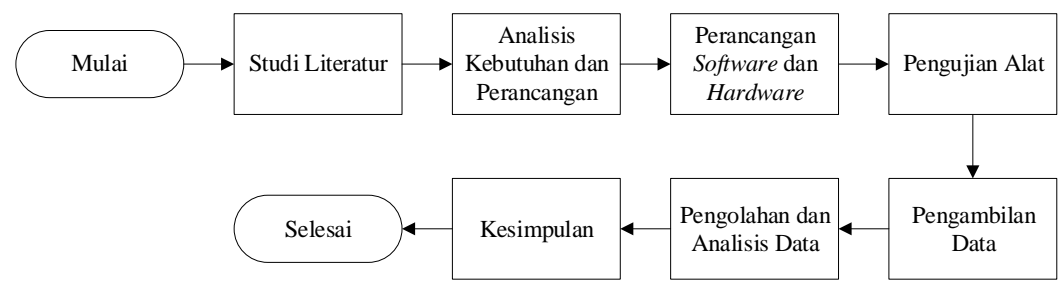

Gambar 1. Diagram Alir Penelitian

Proses penelitian ini dimulai dengan mengidentifikasi masalah dengan mengumpulkan permasalahan yang melatar belakangi pengambilan tema penelitian ini dengan melakukan studi literatur. Setelah dilakukan studi literatur dan ditemukan ide penelitian. Untuk mempermudah perancangan dilakukan proses analisa atau penjabaran kompone yang dibutuhkan dalam mendukung proses kelancaran sistem. Untuk mempermudah menganalisis sebuah sistem dibutuhkan dua jenis kebutuhan. Kebutuhan fungsional dan kebutuhan non fungsional, kebutuhan fungsional adalah kebutuhan yang berisi proses apa saja yang diperlukan oleh sistem, kemudian kebutuhan non fungsional yaitu komponen-komponen yang diperlukan oleh sistem. 


\section{Kuspranoto, Sinaga}

Monitoring Suhu Tubuh dengan Output Suara Berbasis ESP-32CAM

Selanjutnya, perancangan hardware dan software. Langkah awal dalam perancangan sistem ini adalah membuat flowchart algoritma sistem dan blok diagram yang merupakan gambaran dasar untuk merancang dan akhirnya membuat suatu sistem dari alat yang dibuat, sehingga keseluruhan skema rangkaian tersebut akan menghasilkan suatu sistem yang dapat difungsikan atau dapat bekerja sesuai dengan perancangan. Perancangan sistem ini terdiri dari perangkat keras yang aktifitasnya dikendalikan oleh perangkat lunak sehingga semua sistem dapat saling berhubungan. Sistem yang dirancang dapat bekerja secara otomatis bila mendapatkan masukan dari luar.

Setelah perancangan hardware dan perangkat lunak maka langkah selanjutnya adalah melakukan pengujian perangkat lunak, hardware, dan dilakukan pengujian seberapa besar kinerja alat. Setelah melakukan pengujian alat, perangkat lunak, dan hardware maka langkah selanjutnya pengambilan data untuk melihat hasil sistem yang telah dibuat. Setelah mendapatkan data maka langkah selanjutnya dilakukan pengolahan dan Analisa apakah sistem yang telah dibuat pada penelitian ini sudah berhasil dan sesuai rancangan.

\subsection{Rancangan Perangkat Lunak}

Dalam mendukung kerja sistem pada perancangan alat pemantau suhu berbasis ESP32-CAM diperlukan perangkat lunak. Perangkat lunak yang digunakan disini adalah program didalam memori yang harus dilaksanakan oleh ESP32-CAM pada perangkat lunak IDE Arduino dengan Bahasa pemrograman yang digunakan adalah bahasa $\mathrm{C}$ yang terdapat pada IDE Arduino yang dapat langsung bebas diunduh di situs web resmi Arduino yaitu www.arduino.cc. Pengendalian sistem yang berpusat pada ESP32-CAM sepenuhnya diatur oleh program utama software IDE Arduino[12]. Dibawah ini merupakan listing program utama untuk pembacaan suhu tubuh manusia pada penelitian ini.

\subsubsection{Listing Program Utama}

Rancangan software pembacaan suhu tubuh manusia menggunakan sensor yang dideteksi adalah sensor MLX90614. Pembacaan sensor ditunjukkan pada listing program berikut:

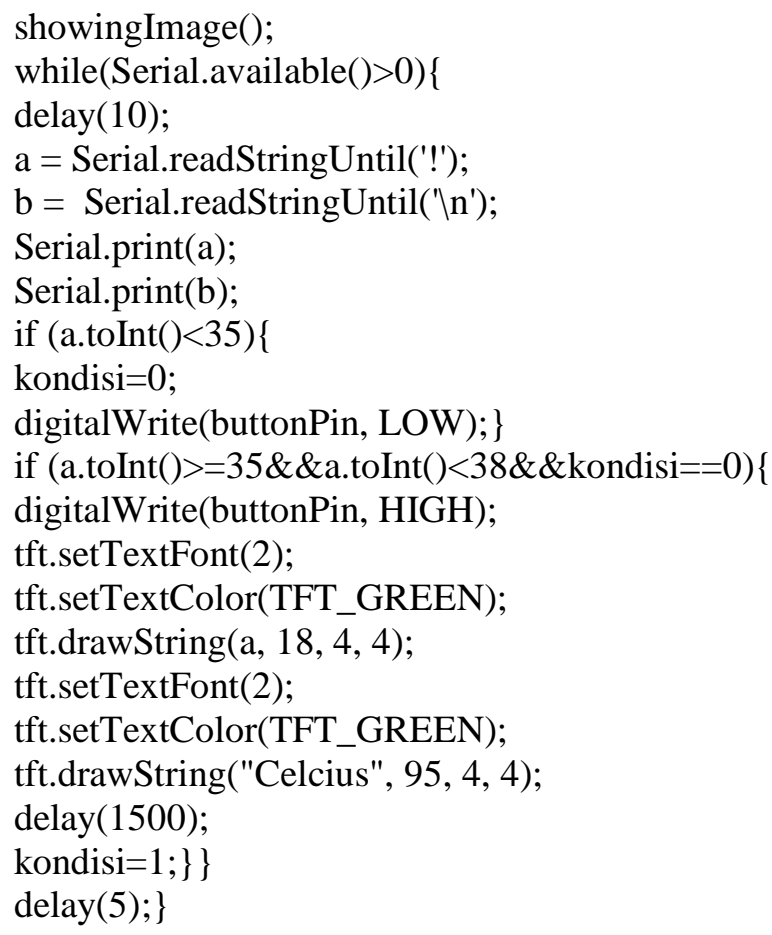

Listing program utama pada penelitian ini akan mendeteksi suhu tubuh manusia terbagi menjadi 2 yaitu normal dan tinggi atau tidak normal, jika $<=35^{\circ} \mathrm{C}$ maka pada layar LCD akan menampilkan suhu normal dengan warna hijau dan speaker akan mengeluarkan suara normal, 


\section{Kuspranoto, Sinaga}

Monitoring Suhu Tubuh dengan Output Suara Berbasis ESP-32CAM

sedangkan jika suhu 35 - 38 atau lebih maka LCD akan menampilkan suhu tidak normal dengan warna merah, dan speaker akan mengeluarkan suara suhu tidak normal.

\subsubsection{Diagram Alir Perangkat Lunak}

Penelitian rancang bangun sistem pemantau suhu berbasis ESP32-CAM ini memiliki diagram alir software yang ditunjukkan pada Gambar 2.

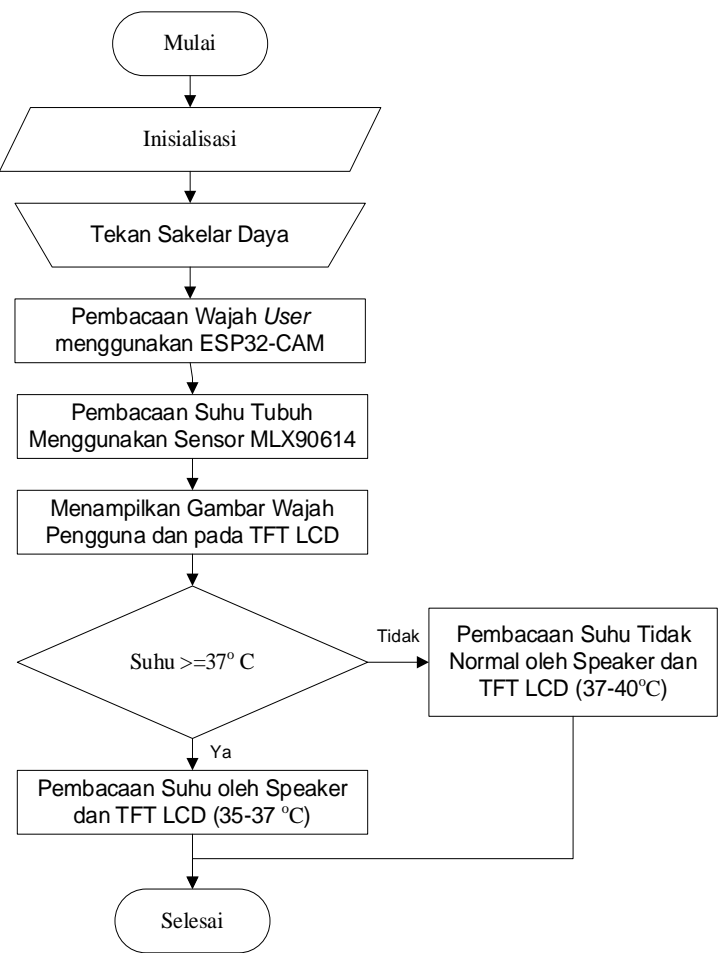

Gambar 2. Diagram Alir Perangkat Lunak Rancang Bangun Sistem Pemantau Suhu Berbasis ESP32-CAM

Gambar 2 merupakan diagram alir perangkat lunak rancang bangun sistem pemantau suhu berbasis ESP32-CAM pada penelitian ini. Diagram alir perangkat lunak pada penelitian ini diawali dengan menekan sakelar daya untuk menyalakan alat, kemudian akan dilakukan inisialisasi, selanjutnya ESP32-CAM akan menangkap gambar wajah pengguna, sensor MLX90614 akan membaca suhu objek dalam hal ini objeknya ialah dahi manusia, kemudian ESP32-CAM akan mengirimkan sinyal perintah untuk menampilkan gambar wajah pengguna kepada TFT LCD untuk ditampilkan, setelah itu ESP32-CAM akan mengirimkan sinyal suhu yang didapatkan dari sensor MLX90614 untuk menampilkan hasil pembacaan suhu menggunakan TFT LCD dan DFPlayer yang akan diteruskan ke speaker untuk dibacakan hasil pembacaan suhu apakah normal atau tidak normal.

Adapun penggunaan input dari mikrokontroler ESP32-CAM adalah sensor MLX90614 dan kamera yang terdapat pada ESP32-CAM, sedangkan hasil output berupa bunyi yang berasal dari speaker yang telah diolah oleh DFPlayer dan tampilan suhu pada LCD. Berikut penjelasan lebih rinci mengenai Input, Proses dan Output dari penelitian ini:

a. Input

Input dari sistem ini ada dua, yaitu sensor MLX90614 dan kamera. Pada input sensor MLX90614 berfungsi sebagai pendeteksi suhu tubuh manusia yang telah ditentukan set point. Input kamera sebagai mengambil gambar manusia dan sebagai penanda bahwa memang manusia yang akan dideteksi oleh sensor MLX90614, dimisalkan jika ada manusia dan diambil gambar oleh kamera maka sensor akan mendeteksi suhu, namun jika bukan manusia maka sensor tetap akan menangkap suhu tubuh namun tidak menampilkan pada LCD dan mengeluarkan suara.

Medika Teknika : Jurnal Teknik Elektromedik Indonesia, Vol 03 No. 1, Oktober 2021 | 11 


\section{Kuspranoto, Sinaga}

Monitoring Suhu Tubuh dengan Output Suara Berbasis ESP-32CAM

b. Kendali

Pada proses dari sistem ini adalah menggunakan perangkat lunak pemrograman Arduino yang sudah diprogram ke dalam ESP32-CAM.

c. Output

Output yang dihasilkan pada penelitian ini yaitu speaker dan tampilan pada LCD. Speaker akan mengeluarkan suara dan menyebutkan suhu yang terbaca oleh sensor MLX0614 ketika sudah sesuai set point yang ditentukan. LCD akan menampilkan angka suhu yang terbaca oleh sensor MLX90614 ketika sudah sesuai dengan set point yang telah ditentukan.

\subsection{Rancangan Perangkat Keras}

Dalam tahap perancangan perangkat keras ini semua komponen yang digunakan akan di jelaskan secara menyeluruh dengan menampilkan rangkaian keseluruhan dan diagram blok pada penelitian ini.

\subsubsection{Diagram Blok Program}

Diagram blok dibuat untuk memberikan kemudahan dalam memahami keseluruhan sistem rancang bangun pada penelitian ini. Diagram blok perancangan sistem dibuat berdasarkan cara kerja rangkaian secara Keseluruhan. Berdasarkan diagram blok pada Gambar 2.3 dapat diketahui komponen input dan output.

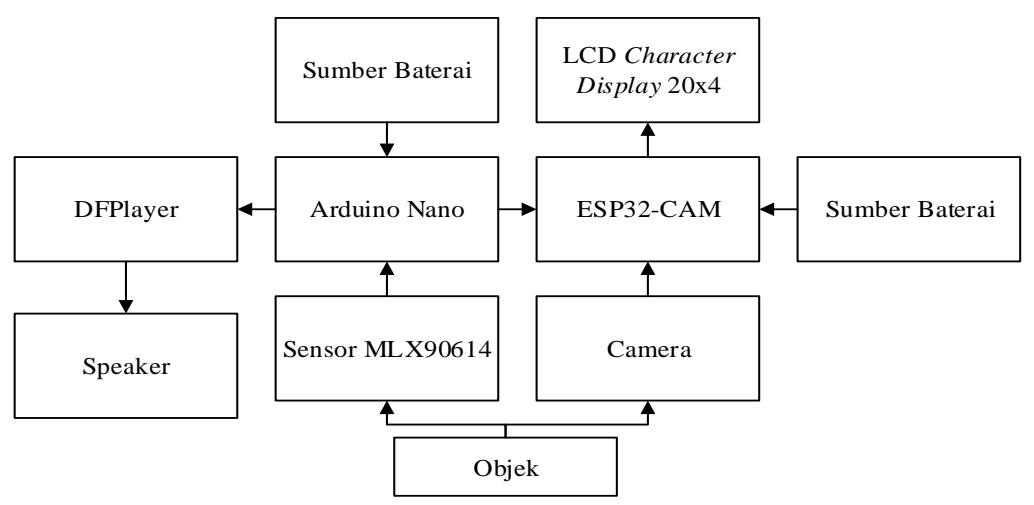

Gambar 3. Diagram Blok Rancang Bangun Sistem Pemantau Suhu Berbasis ESP32-CAM

Gambar 3. menunjukkan diagram blok penelitian ini. Baterai berfungsi sebagai penyuplai tegangan ke seluruh rangkaian pada penelitian ini. Kemudian ESP32-CAM berfungsi sebagai papan untuk kontrol semua rangkaian yang digunakan, pada ESP32-CAM didalamnya sudah termasuk kamera yang akan berfungsi mengambil gambar wajah objek pengguna yang ingin diperiksa suhu tubuhnya, sensor MLX90614 berfungsi sebagai sensor suhu yang digunakan pada penelitian ini. Penelitian ini dirancang untuk mendeteksi suhu tubuh manusia ketika sensor MLX90614 membaca suhu normal manusia yaitu $<=35^{\circ} \mathrm{C}$ dan mendeteksi adanya wajah yang terbaca. Hasil suhu akan terbaca dan di tampilkan pada LCD dan dikeluarkan suara pada speaker yang telah diproses oleh DFPlayer.

\subsubsection{Desain alat}

Rancangan desain alat pemantau suhu tubuh pada penelitian ini terdapat tempat untuk menaruh semua komponen alat berupa box elektronik yang didalamnya terdiri dari saklar, sensor MLX90614, ESP32-CAM, LCD, DFPlayer, speaker dan catu daya. alat penguntrol ESP32-CAM diletakkan dibawah kotak, sedangkan kamera pada ESP32-CAM akan mencuat keluar begitupun dengan sensor MLX90614 dan LCD. Bentuk rancangan alat pada penelitian ini ditunjukkan pada Gambar 4. 


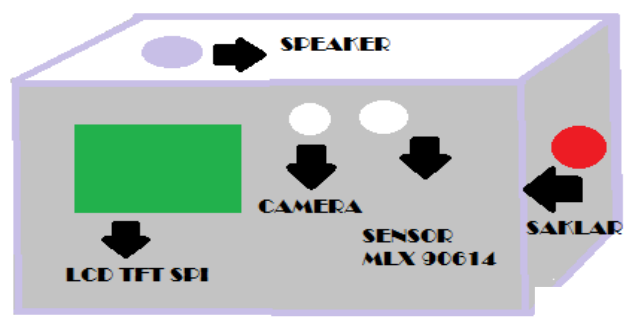

\subsection{Metode pengukuran dan Analisis Data}

Gambar 4. Desain Alat Pemantau Suhu Berbasis ESP32-CAM

Hasil pengukuran merupakan data tentang pengukuran dari masing-masing titik pengukuran yang telah ditentukan untuk mengetahui apakah hasil rangkaian yang dibuat sesuai dengan hasil perencanaan pengukuran yang di lakukan pada beberapa titik pengukuran berikut:

Selisih Tegangan = tegangan berdasarkan datasheet - tegangan aktual

Sedangkan dalam analisa data bertujuan untuk membandingkan hasil teori dengan hasil ukur pada titik pengukuran dan untuk mengetahui besarnya persentase kesalahan pada rangkaian yang dibuat, untuk mengetahui persentasi kesalahan dapat diketahui dengan rumus sebagai berikut:

$$
\text { Persentase Kesalahan (\%) }=\left[\frac{\text { Selisih Pengukuran Thermogun dan MLX90614 }}{\text { hasil ukur Thermogun }}\right] \times 100 \%
$$

\section{HASIL DAN PEMBAHASAN}

Bab ini menyajikan hasil akhir penelitian ini termasuk pengujian fungsi alat, pengujian dan analisis dari Rancang Bangun Sistem Pemantau Suhu Berbasis ESP32-CAM dilakukan dengan cara mengumpulkan data-data dengan beberapa kali pengujian dengan jarak pengukuran yang telah ditentukan.

\subsection{Pengujian Tegangan Pada Titik Input Komponen}

Mengetahui apakah komponen dan rangkaian yang digunakan berfungsi dengan baik, dilakukan pengujian pengukuran tegangan pada ESP32-CAM, DFPlayer, dan sensor MLX90614. Hasil pengukuran aktual akan dibandingkan dengan tegangan sesuai toeri (datasheet) untuk mengetahui nilai selisihinya. Setelah pengujian dilakukan didapatkan hasil sebagaimana yang ditunjukkan pada Tabel 1.

Tabel 1. Hasil Perbandingan Pengukuran Tegangan Komponen

\begin{tabular}{|c|c|c|c|}
\hline Titik Pengukuran & Tegangan Aktual (V) & Tegangan Teori (V) & Selisih \\
\hline ESP32-CAM & 4,91 & 5 & 0,09 \\
\hline DFPlayer & 4,85 & 5 & 0,15 \\
\hline MLX90614 & 3,4 & 3.3 & 0,1 \\
\hline
\end{tabular}

Tabel 1. menunjukkan nilai tegangan berdasarkan titik masukan pengukuran pada ESP32CAM, DFPlayer, dan sensor MLX90614. Berdasarkan Tabel 1. hasil tegangan pada titik pengukuran tiga komponen menunjukkan sesilih tegangan namun masih dalam batas toleransi sehingga rangkaian dapat berjalan dengan baik. Pada ESP32-CAM menunjukkan tegangan hasil pengukuran sebesar 4,91 Volt sedangkan berdasarkan teori menunjukkan seharusnya tegangan terbaca sebesar 5 Volt dan terdapat selisih sebesar 0,09 Volt. Pada DFPlayer menunjukkan tegangan hasil pengukuran sebesar 4,85 Volt sedangkan berdasarkan teori menunjukkan seharusnya tegangan terbaca sebesar 5 Volt dan terdapat selisih sebesar 0,15 Volt. Pada sensor MLX90614 menunjukkan tegangan hasil pengukuran sebesar 3,4 Volt sedangkan berdasarkan teori menunjukkan seharusnya tegangan terbaca sebesar 3,3 Volt dan terdapat selisih sebesar 0,1 Volt. Selisih tegangan pada titik pengukuran yang dilakukan jika dibandingkan dengan hasil tegangan berdasarkan teori disebabkan oleh banyak hal, seperti toleransi pada alat ukur yang digunakan memiliki tolerasi hasil pengukuran, penyebab selisih tegangan juga dapat terjadi akibat toleransi 


\section{Kuspranoto, Sinaga}

Monitoring Suhu Tubuh dengan Output Suara Berbasis ESP-32CAM

dari komponen yang digunakan memiliki toleransi tegangan, semakin bagus sebuah komponen yang digunakan maka akan semakin kecil toleransi tegangannya.

\subsection{Pengujian Suhu Tubuh Manusia Dengan Jarak Yang Berbeda}

Dalam mengetahui apakah alat yang dirancang berfungsi dengan baik, dilakukan pengujian alat pengukuran suhu yang dilakukan dengan meletakkan alat di depan dahi partisipan dengan jarak yang berbeda-beda yaitu dari $3 \mathrm{~cm}, 5 \mathrm{~cm}, 7 \mathrm{~cm}, 9 \mathrm{~cm}, 11 \mathrm{~cm}, 13 \mathrm{~cm}$, dan $15 \mathrm{~cm}$. Alat yang dibuat dibandingkan dengan thermometer gun pabrikan. Pengujian ini dilakukan pada partisipan dengan catatan bahwa partisipan berada dalam kondisi yang sehat. Setelah pengujian dilakukan didapatkan hasil sebagaimana yang ditunjukkan pada Tabel 2 dan Gambar 5.

Tabel 2 Hasil Pengukuran Suhu Tubuh Manusia dengan Menggunakan Thermometer gun dan MLX90614

\begin{tabular}{|c|c|c|c|c|}
\hline \multirow{2}{*}{$\begin{array}{c}\text { Jarak } \\
(\mathbf{c m})\end{array}$} & \multicolumn{2}{|c|}{ Hasil Pengukuran Suhu } & \multirow{2}{*}{$\begin{array}{c}\text { Selisih } \\
\left({ }^{\circ} \mathbf{C}\right)\end{array}$} & \multirow{2}{*}{$\begin{array}{c}\text { Galat } \\
(\%)\end{array}$} \\
\hline & MLX90614 $\left({ }^{\circ} \mathrm{C}\right)$ & Thermometer Gun $\left({ }^{\circ} \mathbf{C}\right)$ & & \\
\hline 3 & 34.2 & 34.3 & 0.1 & $0.29 \%$ \\
\hline 3 & 34.5 & 34.9 & 0.4 & $1.15 \%$ \\
\hline 3 & 34.1 & 34.2 & 0.1 & $0.29 \%$ \\
\hline Rata-Rata & 34.27 & 34.47 & 0.20 & $0.58 \%$ \\
\hline 5 & 33.7 & 34.3 & 0.6 & $1.75 \%$ \\
\hline 5 & 34.1 & 34.8 & 0.7 & $2.01 \%$ \\
\hline 5 & 34.12 & 34.5 & 0.38 & $1.10 \%$ \\
\hline Rata-Rata & 33.97 & 34.53 & 0.56 & $1.62 \%$ \\
\hline 7 & 34.17 & 34.2 & 0.03 & $0.09 \%$ \\
\hline 7 & 33.88 & 34.7 & 0.82 & $2.36 \%$ \\
\hline 7 & 33.71 & 34.6 & 0.89 & $2.57 \%$ \\
\hline Rata-Rata & 33.92 & 34.50 & 0.58 & $1.67 \%$ \\
\hline 9 & 33.24 & 34.1 & 0.86 & $2.52 \%$ \\
\hline 9 & 33.91 & 34.7 & 0.79 & $2.28 \%$ \\
\hline 9 & 33.45 & 34.2 & 0.75 & $2.19 \%$ \\
\hline Rata-Rata & 33.53 & 34.33 & 0.80 & $2.33 \%$ \\
\hline 11 & 31.69 & 32.5 & 0.81 & $2.49 \%$ \\
\hline 11 & 33.56 & 34.4 & 0.84 & $2.44 \%$ \\
\hline 11 & 33.68 & 34.5 & 0.82 & $2.38 \%$ \\
\hline Rata-Rata & 32.98 & 33.80 & 0.82 & $2.44 \%$ \\
\hline 13 & 31.61 & 32.5 & 0.89 & $2.74 \%$ \\
\hline 13 & 33.57 & 34.43 & 0.86 & $2.50 \%$ \\
\hline 13 & 33.51 & 34.43 & 0.92 & $2.67 \%$ \\
\hline Rata-Rata & 32.90 & 33.79 & 0.89 & $2.64 \%$ \\
\hline 15 & 31.12 & 32.1 & 0.98 & $3.05 \%$ \\
\hline 15 & 33.13 & 34.1 & 0.97 & $2.84 \%$ \\
\hline 15 & 33.31 & 34.2 & 0.89 & $2.60 \%$ \\
\hline Rata-Rata & 32.52 & 33.47 & 0.95 & $2.83 \%$ \\
\hline
\end{tabular}

Tabel 2 menunjukkan nilai rerata selisih kesalahan hasil pengukuran antara thermometer gun dan MLX90614. Berdasarkan Tabel 2 hasil rerata galat pengukuran suhu terbesar terdapat pada jarak pengukuran $15 \mathrm{~cm}$ dengan selisih sebesar $0,95^{\circ} \mathrm{C}$ dan dengan persentase galat sebesar $2.83 \%$. Hasil rerata galat pengukuran suhu terkecil terdapat pada jarak pengukuran $3 \mathrm{~cm}$ dengan selisih sebesar $0,2^{\circ} \mathrm{C}$ dan dengan persentase galat sebesar $0,58 \%$.

Hasil pengukuran suhu tubuh tertinggi manusia yang di dapat dengan menggunakan thermometer gun pada bagian dahi sebesar $34,9^{\circ} \mathrm{C}$ yang terdapat pada jarak $3 \mathrm{~cm}$. Untuk hasil pengukuran suhu tubuh tertinggi manusia yang di dapat oleh alat pengukur suhu tubuh menggunakan MLX90614 pada bagian dahi sebesar $34,5^{\circ} \mathrm{C}$ yang terdapat pada jarak $3 \mathrm{~cm}$. Hasil pengukuran suhu tubuh terendah manusia yang di dapat oleh thermometer gun pada bagian dahi

Medika Teknika : Jurnal Teknik Elektromedik Indonesia, Vol 03 No. 1, Oktober 2021 | 14 


\section{Kuspranoto, Sinaga}

Monitoring Suhu Tubuh dengan Output Suara Berbasis ESP-32CAM

sebesar $32,1^{\circ} \mathrm{C}$ yang terdapat pada jarak $15 \mathrm{~cm}$. Untuk hasil pengukuran suhu tubuh terendah manusia yang di dapat oleh alat pengukur suhu tubuh menggunakan MLX90614 pada bagian dahi sebesar $31,12^{\circ} \mathrm{C}$ yang terdapat pada jarak $15 \mathrm{~cm}$.

Setelah dilakukannya pengujian dengan jarak $3 \mathrm{~cm}, 5 \mathrm{~cm}, 7 \mathrm{~cm}, 9 \mathrm{~cm}, 11 \mathrm{~cm}, 13 \mathrm{~cm}$, dan 15 $\mathrm{cm}$ didapatkan bahwa hasil rerata pengukuran suhu pada jarak $3 \mathrm{~cm}$ oleh alat pengukur suhu tubuh menggunakan MLX9614 dibandingkan dengan thermometer gun mempunyai selisih $0,2^{\circ} \mathrm{C}$ dengan galat sebesar $0,58 \%$, sedangkan pada jarak $15 \mathrm{~cm}$ mempunyai rerata selisih yang cukup jauh yaitu sebesar $0,95^{\circ} \mathrm{C}$ dengan galat sebesar $2,83 \%$. Dengan demikian dapat diketahui jarak objek dengan alat pengukur suhu tubuh menggunakan MLX90614 mempengaruhi hasil pengukuran dimana sensor memiliki field of view (FOV) yang hanya mampu membaca secara akurat pada kisaran jarak $3 \mathrm{~cm}$. Jika pengukuran dengan jarak lebih dari $3 \mathrm{~cm}$ maka FOV sensor akan mendeteksi objek lain pada daerah bacalapang pandangnya dan menimbulkan disturbance (gangguan) yang mengakibatkan ketidakakuratan pada pengukuran suhu. Semakin jauh jarak pengukuran hasil yang didapatkan maka akan semakin besar nilai selisih dan nilai galatnya.

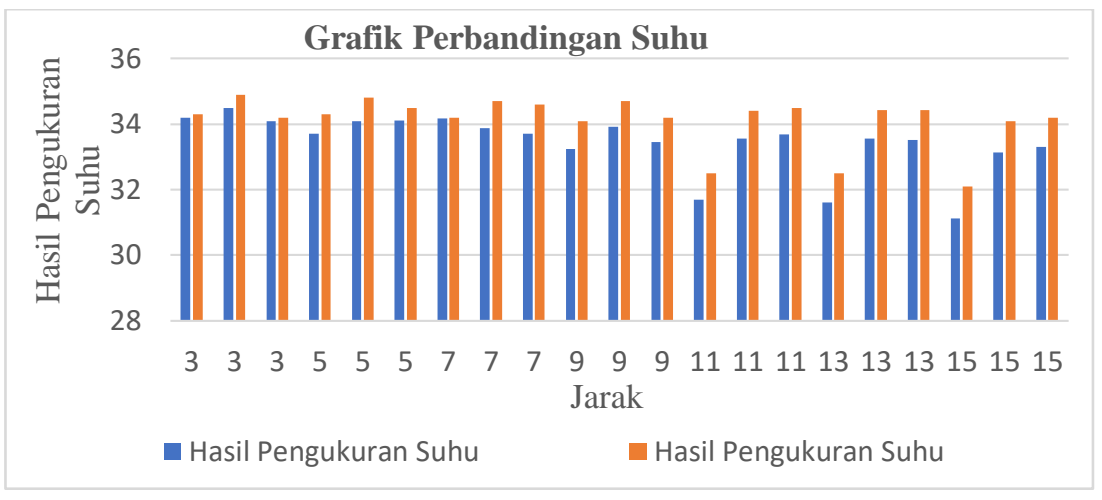

Gambar 5. Grafik Perbandingan Suhu Thermometer Gun dengan MLX90614

Gambar 5 menunjukkan grafik perbandingan pengambilan data suhu tubuh manusia antara menggunakan thermometer gun dan dengan menggunakan MLX90614 berdasarkan jarak pengambilan suhu tubuh manusia yaitu dari jarak $3 \mathrm{~cm}, 5 \mathrm{~cm}, 7 \mathrm{~cm}, 9 \mathrm{~cm}, 11 \mathrm{~cm}, 13 \mathrm{~cm}$, dan 15 $\mathrm{cm}$. Berdasarkan grafik pada Gambar 5 dapat dilihat bahwa hasil pengukuran suhu tubuh manusia menggunakan MLX90614 memiliki hasil pengukuran yang tidak terlampau jauh selisihnya terhadap hasil pengukuran thermometer gun, namun dapat terlihat bahwa semakin jauh jarak pengukuran maka hasil pengukuran akan mempunyai selisih yang cukup jauh dan akan memiliki nilai galat yang semakin besar jika dibandingkan dengan thermometer gun.

\subsection{Hasil Perhitungan Selisih dan Galat Pengukuran Suhu}

Untuk mengetahui apakah alat yang dirancang pada penelitian ini berfungsi dengan baik, maka perlu dilakukan perhitungan persentase galat dengan membandingkan antara alat pada penelitian ini dengan thermometer gun yang kemudian akan dihitung selisih dan persentase galat berdasarkan persentase kesalahan.

Berdasarkan hasil uji analisis pada Tabel 2 dapat disimpulkan bahwa dapat diketahui jarak objek dengan alat pengukur suhu tubuh menggunakan MLX90614 mempengaruhi hasil pengukuran dimana sensor memiliki field of view (FOV) yang hanya mampu membaca secara akurat pada kisaran jarak $3 \mathrm{~cm}$. Jika pengukuran dengan jarak lebih dari $3 \mathrm{~cm}$ maka FOV sensor akan mendeteksi objek lain pada daerah bacalapang pandangnya dan menimbulkan disturbance (gangguan) yang mengakibatkan ketidakakuratan pada pengukuran suhu. Semakin jauh jarak pengukuran hasil yang didapatkan maka akan semakin besar nilai selisih dan nilai galatnya.

\subsection{Hasil Pengujian Keluaran Suara}

Modul DFPlayer adalah modul suara yang harus diuji dengan bantuan program dari Arduino nano, karena modul tersebut dikontrol secara digital melalui perintah dengan komunikasi serial.

Medika Teknika : Jurnal Teknik Elektromedik Indonesia, Vol 03 No. 1, Oktober 2021| 15 


\section{Kuspranoto, Sinaga}

Monitoring Suhu Tubuh dengan Output Suara Berbasis ESP-32CAM

Untuk itu program dibuat untuk pengujian tersebut dan dijalankan berbarengan dengan Arduino nano. Program dibuat untuk memainkan file suara yang ada pada memori SDcard dimana SDCard telah ada beberapa file suara yang dibutuhkan. File suara tersebut bertipe mp3[13]. Keluaran suara pada alat ini menggunakan modul DFPlayer yang dihubungkan pada speaker untuk mengubah besaran listrik menjadi suara.

Tabel 3. Pengujian Modul DFPlayer

\begin{tabular}{|c|c|}
\hline Perintah Program & Output Suara \\
\hline mp3_play (1); & Satu \\
\hline mp3_play (2); & Dua \\
\hline mp3_play (3); & Tiga \\
\hline mp3_play (11); & Puluh \\
\hline mp3_play (12); & Suhu Tubuh Anda \\
\hline mp3_play (13); & Derajat Celcius \\
\hline
\end{tabular}

Setelah pengujian Modul DFPalyer, diperlukannya pengujian terhadap keluaran suara tersebut, apakah sesuai dengan suhu yang ditampilkan atau tidaknya. Pengujian keluaran suara pada alat ini yaitu membandingkan suhu yang ditampilkan pada display dengan suara yang dihasilkan dengan display pada alat. Hasil dari pengujian keluaran suara ditunjukkan pada Tabel 4

Tabel 4. Pengujian Keluaran Suara Modul DFPlayer Terhadap Suhu Pada Display

\begin{tabular}{|c|c|c|}
\hline Pengujian Suhu $\left({ }^{\circ} \mathrm{C}\right)$ & Display TFT & Suara DFPlayer \\
\hline 30 & $30{ }^{\circ} \mathrm{C}$ & Tiga Puluh \\
\hline 31 & $31{ }^{\circ} \mathrm{C}$ & Tiga Puluh Satu \\
\hline 32 & $32{ }^{\circ} \mathrm{C}$ & Tiga Puluh Dua \\
\hline 33 & $33^{\circ} \mathrm{C}$ & Tiga Puluh Tiga \\
\hline 34 & $34{ }^{\circ} \mathrm{C}$ & Tiga Empat \\
\hline 35 & $35{ }^{\circ} \mathrm{C}$ & Tiga Puluh Lima \\
\hline 36 & $36{ }^{\circ} \mathrm{C}$ & Tiga Puluh Enam \\
\hline 37 & $37^{\circ} \mathrm{C}$ & Tiga Puluh Tujuh \\
\hline 38 & $38^{\circ} \mathrm{C}$ & $\begin{array}{c}\text { Suhu Anda Melebihi } \\
\text { Batas Normal }\end{array}$ \\
\hline 39 & $39{ }^{\circ} \mathrm{C}$ & $\begin{array}{c}\text { Suhu Anda Melebihi } \\
\text { Batas Normal }\end{array}$ \\
\hline
\end{tabular}

Dari Tabel 4. menunjukkan hasil yang sesuai ketika dibandingkan keluaran suara dengan suhu yang ditampilkan. Pada suhu diatas $37{ }^{\circ} \mathrm{C}$ keluaran suara dibuat berbeda karena sebagai petanda suhu tubuh melebihi batas normal dengan keluaran suara "Suhu Anda Melebihi Batas Normal”.

\section{KESIMPULAN}

Berdasarkan hasil penelitian, analisis, dan uji fungsi rancang bangun sistem pemantau suhu berbasis ESP32-CAM maka dapat diambil kesimpulan pada Tabel 1 bahwa hasil tegangan masukan berdasarkan titik pengukuran pada komponen ESP32-CAM, DFPlayer, sensor MLX90614 memiliki selisih yang masih dalam toleransi yaitu kurang dari 0.5 Volt. Pada ESP32-CAM memiliki selisih tegangan sebesar 0,09 Volt, pada DFPlayer memiliki selisih tegangan sebesar 0,15 Volt, pada sensor MLX90614 memiliki selisih tegangan sebesar 0,1 Volt. Rangkaian dan alat dapat bekerja dengan baik karena masih dalam toleransi tegangan.

Selanjutnya hasil analisa pada Tabel 2 dapat disimpulkan bahwa dapat diketahui jarak objek dengan alat pengukur suhu tubuh menggunakan MLX90614 mempengaruhi hasil pengukuran dimana sensor memiliki field of view (FOV) yang hanya mampu membaca secara akurat pada kisaran jarak $3 \mathrm{~cm}$. Jika pengukuran dengan jarak lebih dari $3 \mathrm{~cm}$ maka FOV sensor akan mendeteksi objek lain pada daerah bacalapang pandangnya dan menimbulkan disturbance 


\section{Kuspranoto, Sinaga}

Monitoring Suhu Tubuh dengan Output Suara Berbasis ESP-32CAM

(gangguan) yang mengakibatkan ketidakakuratan pada pengukuran suhu. Semakin jauh jarak pengukuran hasil yang didapatkan maka akan semakin besar nilai selisih dan nilai galatnya.

\section{DAFTAR PUSTAKA}

[1] A. Rafikasari, "Formulating Indonesia's Covid-19 Policy based on South Korea's Experience," J. Humanit. Educ. Dev., vol. 2, no. 3, pp. 170-176, 2020.

[2] T. Liang, "Handbook of COVID-19 Prevention and Treatment," Handb. Covid-19, Prev. Treat., p. 68, 2020.

[3] R. Djalante et al., "Review and analysis of current responses to COVID-19 in Indonesia: Period of January to March 2020," Prog. Disaster Sci., vol. 6, no. April, p. 100091, 2020.

[4] World Health Organization, "WHO Coronavirus Disease (COVID-19) Dashboard," 2021. .

[5] D. Krisnawati, A. Trisiana, E. Mey, V. Elvidna, Y. M. B. Puspa, and Z. Mardiana, "Ketahanan Negara Republik Indonesia Masa Pandemik Covid-19," J. Glob. Citiz. J. Ilm., vol. 9, no. 1, pp. 63-70, 2020.

[6] H. N. Ulya, "Alternatif Strategi Penanganan Dampak Ekonomi Covid-19 Pemerintah Daerah Jawa Timur Pada Kawasan Agropolitan," El-Barka J. Islam. Econ. Bus., vol. 3, no. 1, pp. 80-109, 2020.

[7] B. O. Akinloye, A. O. Onyan, and D. E. Oweibor, "Design and Thermometer Implementation With of Digital Clock," Glob. J. Eng. Res., vol. 15, no. 1, pp. 1-10, 2016.

[8] M. Wartono, B. Puruhito, and A. A. Adrianto, "Kesesuaian Termometer Inframerah Dengan Termometer Air Raksa Terhadap Pengukuran Suhu Aksila Pada Usia Dewasa Muda (18-22 Tahun)," Diponegoro Med. J. (Jurnal Kedokt. Diponegoro), vol. 7, no. 2, pp. 1520-1529, 2018.

[9] B. P. R. Sued et al., "Sphygmomanometers and thermometers as potential fomites of Staphylococcus haemolyticus: Biofilm formation in the presence of antibiotics," Mem. Inst. Oswaldo Cruz, vol. 112, no. 3, pp. 188-195, 2017.

[10] Safitri M, Dinata GA. Non-Contact Thermometer Berbasis Infra Merah. Simetris J Tek Mesin, Elektro dan Ilmu Komput. 2019;10(1):21-6.

[11] Padma Diana IPA, Putu Raka Agung IGA, Rahardjo P. Perancangan Modul Pembelajaran Huruf Braille Berbasis Mikrokontroler Untuk Membantu Proses Belajar Disabilitas Netra. J SPEKTRUM. 2018;5(1):5.

[12] Pratama RP, Mas'ud A, Niswatin C, Rafiq AA. Implementasi DFPlayer untuk Al-Qur'an Digital berbasis Mikrokontroler ESP32. INVOTEK J Inov Vokasional dan Teknol. 2020;20(2):51-8.

[13] Sitanggang,Hotrini.Pembuatan Alat Bantu Jalan Untuk Tunanetra Menggunakan Sensor Ultrasonik Dengan Output Suara Universitas Sumatera Utara.2021. 